\title{
$\mathrm{C}|\mathrm{E}| \mathrm{D}|\mathrm{L}| \mathrm{A} \mid \mathrm{S}$
}

Centro de Estudios

Distributivos, Laborales y Sociales

Maestría en Economía

Universidad Nacional de La Plata

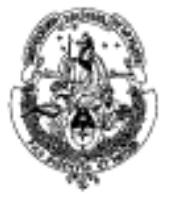

\section{Educational Reform and Labor Market Outcomes: the Case of Argentina's Ley Federal de Educación}

\section{María Laura Alzúa, Leonardo Gasparini y Francisco Haimovich}

\author{
Documento de Trabajo Nro. 111
}

Diciembre, 2010

ISSN 1853-0168 


\title{
Educational Reform and Labor Market Outcomes: the Case of Argentina's Ley Federal de Educación*
}

\author{
María Laura Alzúa \\ Leonardo Gasparini \\ Francisco Haimovich \\ $\mathbf{C}|\mathbf{E}| \mathbf{D}|\mathbf{L}| \mathbf{A} \mid \mathbf{S}^{* * *}$ \\ Universidad Nacional de La Plata
}

\begin{abstract}
In the nineties Argentina implemented a large education reform (Ley Federal de Educación LFE) that mainly implied the extension of compulsory education in two additional years. The timing in the implementation substantially varied across provinces, providing a source of identification for unraveling the causal effect of the reform. The estimations from difference-indifference models suggest that the LFE had an overall positive although mild impact on education and labor outcomes. The impact on the income-deprived youths was small for education outcomes and null for labor outcomes.
\end{abstract}

\section{Resumen}

En los noventa Argentina implementó una reforma educativa (la Ley Federal de Educación LFE) que implicó principalmente la extensión de la educación obligatoria en dos años adicionales. El timing en la implementación fue sustancialmente diferente entre provincias, lo cual provee una fuente de identificación del efecto causal de la reforma. Las estimaciones de modelos de diferencias dobles sugieren que la LFE tuvo un impacto global positivo pero moderado sobre los resultados educativos y laborales. El impacto sobre los jóvenes pobres fue pequeño en términos educativos y nulo en términos laborales.

Código JEL: I2, I3

\footnotetext{
* The authors would like to thank Verónica Amarante, Germán Bet, John Hoddinott, Harry Patrinos, Steven Machin, Chris Ryan, Ana Santiago, Martín Valdivia and Fabio Veras Soares for their useful comments to earlier drafts of this paper. This research has been possible thanks to the Policy and Economic Policy (PEP) Network financial support.

*** Centro de Estudios Distributivos, Laborales y Sociales, Facultad de Ciencias Económicas, Universidad Nacional de La Plata. Calle 6 entre 47 y 48, 5to. piso, oficina 516, (1900) La Plata, Argentina. Phone-fax: 54-221-4229383. Web site: cedlas.econo.unlp.edu.ar
} 


\section{Introduction}

In 1993 the Argentine Congress passed a law (Ley Federal de Educación, LFE henceforth) aimed at changing some important characteristics of the educational system. Chiefly among them, there was an extension in the years of compulsory education along with a change in the structure of the educational curricula. While in the previous system a child was obliged to attend seven years of primary school, under the new legislation that compulsory educational level was extended to nine years.

By increasing the obligatory number of years of education, the government sought to force mostly poor children to increase their human capital accumulation, and induce some of them to continue studying in the secondary level, and hopefully into college. More educated youths are expected to perform better in the labor market, and hence have a lower probability of falling into poverty. While evidence on the relationship of time spent at school and improvements in the labor market is well established for developed countries, evidence for developing countries is much scarcer (Duflo, 2001, Galiani et al, 2007, Madeira, 2005, Rodriguez, 2005).

In this paper we evaluate the impact of the LFE on several educational and labor outcomes by exploiting the regional heterogeneity in the timing of the reform. Argentina is a federal country where primary and secondary public education are administered and financed at the provincial level. Although the LFE was a federal law to be complied with in all provinces, there was flexibility for state governments to decide on the timing of the reform. While in some provinces the reform was quickly implemented after the LFE was passed, in others the pace of the changes was slower. In fact, in some districts many central aspects of the reform were never implemented.

Taking advantage of this source of variation in the exposition to the "treatment", we study the impact on different educational and labor market outcomes. In particular, we are interested in evaluating whether poor youngsters who were forced to attend two additional school years were then more likely to finish high school, and performed better in the labor market.

The rest of this paper is organized as follows. The education reform is described in section 2 . Section 3 presents the methodology and describes the data sources. Section 4 presents the main results on the effects of the LFE on education and labor market variables. Finally, section 5 concludes.

\section{The Educational Reform}

In the early nineties Argentina decentralized the provision of schooling services, previously in hands of the federal government. ${ }^{1}$ The enactment of the Ley Federal de Educación (LFE) on April 14 ${ }^{\text {th }}, 1993$ (Law 24195) introduced a second set of reforms, among which a significant change in the structure of the educational curricula and the

\footnotetext{
${ }^{1}$ Decentralization has been one of the main recent institutional innovations in development countries. The main idea behind decentralizations is to bring decision making closer to the citizens, so their preferences are better reflected in policies (Oates, 1972). Evidence for Latin America indicates that decentralization in the provision of schooling has increased (decreased) test scores in richer (poorer) districts for the case of Argentina (Galiani et al, 2007). For Brazil, decentralization had a positive effect on test scores too (Madeira, 2006). Finally, for the case of Colombia (Rodriguez, 2006) results indicate that, once adjusting for the composition effect, test scores increased as a result of the decentralization.
} 
extension of mandatory education stand out. ${ }^{2}$ While in the old system a child was obliged to attend seven years of primary school, under the new legislation that compulsory educational level was extended to nine years. In fact, the LFE implied the reorganization of the levels in which the educational system in Argentina is divided. The main changes were:

- Pre-primary education for children aged five became compulsory.

- The primary level, which comprised seven years in the previous law, was replaced by a nine-year level named Educación General Básica (EGB).

- The five years of high school education were replaced by a three-year level called Polimodal.

Table 1 shows the structure of the educational system before and after the reform. The first column reports the age in which the child/youth is supposed to be attending each level.

One of the main goals of the LFE was reducing the high dropout rate in the initial years of secondary school, especially by poor students (Braslavsky, 1999). ${ }^{3}$ Under the new structure youths were "forced" (or encouraged) to stay two years more in school. Advocators of the LFE argued that this extension may also induce many of them to complete the, now shorter, high school level, and hopefully to get into the tertiary level. Other authors are more skeptical. Rivas (2003), among others, suggests that the increase in the enrollment rate during mandatory education may be compensated later with a higher dropout rate in the non compulsory stage.

The increase in the years of compulsory education was accompanied by other institutional changes also aimed at keeping youths at school for longer. The change in the curricula included several specializations in the Polimodal which could be chosen by students according to their preferences, a system that could make the transition to higher education easier. Also, considering that the implementation of the reform was expected to induce an increasing pressure over the educational facilities, a budget of around US\$3,000 million was allocated for an extensive program of investment in both educational infrastructure and training.

An important point for our analysis is that the new legislation was implemented with a substantial variation in terms of timing and intensity across provinces. Argentina is a federal country where primary and secondary public education are administered and financed at the provincial level. Although the LFE was a federal law to be complied with in all provinces, there was flexibility for state governments to decide on the timing of the reform. In fact, provinces were allowed to phase the implementation of the reform along the period 1995-1999. While in some states the reforms were quickly and massively implemented, in others the changes were put into effect more gradually, involving a much smaller percentage of schools. ${ }^{4}$ Moreover, in some districts some central aspects of the reform were never implemented (city of Buenos Aires, and the province of Río

\footnotetext{
${ }^{2}$ This is a somehow different change that the one observed in developed countries, which increase the age for which school is mandatory. The policy in Argentina was to increase the number of compulsory years, regardless of age.

${ }^{3}$ The year Congress passed the law, the net enrolment rate in secondary school was around $65 \%$ for all (urban) Argentina, while it was below $50 \%$ in the bottom quintile of the income distribution (CEDLAS, 2007).

${ }^{4}$ See Rivas (2003) and Crosta (2008).
} 
Negro). Table 2 reports for each province the year of implementation of the LFE and the modality (full, gradual, or null). By year 2000 the majority of the Argentina's provinces were complying with the new legislation.

The principal objective of the reform was to reduce the high dropout rates in the first years of high school and to contribute to improve labor market outcomes. There is a great deal of literature studying the effects of additional schooling on subsequent gains later in life, related mainly to labor market outcomes (Angrist and Kruger (1991) and Acemoglu and Angrist (2000) for the US, Walker (1995) for the UK and Oreopoulos (2007) for Canada). Also, there are some studies which look at other outcomes such as crime (Lochner and Moretti, 2004) and teen pregnancy (Black, Devereux and Salvanes, 2004). However, as Oreopoulos (2007) states, these studies look at changes in compulsory schooling laws that took place many decades ago in developed countries and the studies affecting dropout at that time may be different from the ones affecting dropouts today. Furthermore, the above mentioned studies look at changes in the age a student should remain in school. Out paper looks at a somehow different change, since we examine the number of years that the individual must remain at school, regardless of her age. Duflo (2001) is one the main contributions to this literature for a developing country. She studies the effect of a large school construction program in Indonesia aimed at increasing enrollment in poor areas during the seventies- on labor market outcomes. Duflo (2001) focuses on elementary education. To the best of our knowledge, our study is the first one assessing the effect of an educational reform affecting students at older ages on labor market outcomes in a developing country.

\section{Methodology}

The implementation of the LFE was not accompanied by any strategy to evaluate its impact. This forces us to rely on observational data to derive our results. Our analysis seeks to identify the effect of the implementation of the LFE on several educational and labor outcomes by exploiting the variation in both the timing -early vs. late- and the intensity -full vs. gradual- of the reform across Argentine provinces.

Figures 1 to 3 help to motivate this strategy. Figure 1 shows that while enrollment for children aged 6 to 12 remained almost universal during the period under analysis, enrollment rates for youths aged 13 to 15 substantially increased after provinces started implementing the reform in 1996. Figures 2 and 3 show enrollment rates for ages 13-15 according to the timing (early vs. late) and degree (massive vs. gradual) of the implementation of the educational reform. Enrollment rates seem to have strongly increased for those youngsters living in areas where the LFE was quickly and fully implemented.

One of the basic points of the paper is to evaluate whether youngsters who were affected by the LFE performed better in certain dimensions (e.g. the labor market) than their peers who were not "treated", either because they were born in provinces that did not implement the reform quickly, or because they were not affected by the LFE as they were just leaving primary school when the law was passed.

We use a difference-in-difference approach for our estimations. Specifically, we use fixed-effects methods to control for unobserved heterogeneity across both cohorts and urban areas. Essentially, fixed-effects identification strategy uses repeated observations of the unit of analysis to control for unchanged unobservable characteristics (in this case 
by cohorts or urban areas) that can be correlated with both causal variables and outcomes of interest (Angrist and Krueger, 1998). Our strategy is similar to that of Duflo (2001), who analyzes the impact of an extended school construction program, using the interaction between cohort indicators and program intensity as an instrument for schooling. Formally, the basic model is:

$$
Y_{i j k}=C+\alpha_{j}+\beta_{k}+\theta X_{i}+\left(P_{j} * T_{i}\right) \cdot \gamma+e_{i j k}
$$

where

$\mathrm{Y}_{i j k}=$ outcome of interest of individual $i$, living in city $j$, belonging to cohort $k$.

$\alpha_{j}=$ city fixed effect

$\beta_{k}=$ cohort fixed effect

$X_{i}=$ individual characteristics

$T_{i}=$ treatment variable, equal to 1 if youngsters are treated according to both city and cohort, and 0 otherwise.

$P_{j}=$ measure of the program intensity in the city

$e_{i j k}=$ error term.

A key issue in this strategy is to identify which is the relevant geopolitical unit in order to determine the level of treatment. After the enactment of the LFE, the Argentina's provinces chose whether to adhere or not to this national law and, in case they decided to implement the Reform, they had to select a starting date. The 23 Argentinean provinces and the city of Buenos Aires (Federal District) are listed in table 2, along with the year of implementation of the law. The practical execution of the LFE was not necessarily immediate. In fact, provinces decided whether to make a generalized implementation of the LFE since the beginning, or to follow a gradual strategy.

We define different age cohorts that were exposed to the extension in compulsory education under the new curricula. Besides, there is substantial variability in terms of treatment intensity among the young cohorts. This variability is driven by two main sources. In the first place, differences in the timing of the reform involve that a given cohort could have been exposed to a variable extension in mandatory education according to their city of residence. Second, differences in school construction rates and/or percentage of schools that implemented the reform are another source of variability in the program exposure. Children living in two provinces that implemented the reform in the same year (e.g. Buenos Aires and Córdoba) could be exposed to considerably different treatment intensities in accordance with the investment program carried out to support these reforms.

\section{Outcome variables}

We are interested in measuring the impact of the LFE on human capital accumulation and labor market performance. Clearly, these aspects are strongly linked since more educated youngsters are expected to perform better in the labor market.

Regarding human capital accumulation, we study whether the law was effective in retaining youths in the educational system beyond the compulsory level. As outcome 
indicators we consider years of formal education and secondary school graduation. With respect to the labor market performance of students, the main outcomes considered are earnings, hours worked, and employment.

\section{Data}

Our primary source of information is the Encuesta Permanente de Hogares (EPH) from 2003 to 2006, the main household survey in Argentina. The EPH covers 32 urban areas, with at least one observation in the 24 Argentina's provinces listed in table 2. Although the EPH covers only urban population, and hence it is not nationally representative, the share of rural population in Argentina is, unlike most developing countries, small (13\%). The EPH gathers information on individual's socio-demographic characteristics, employment status, hours of work, wages, incomes, type of job, and education. The EPH includes information on about 100,000 individuals.

Though the units of observation in our research are the individuals, the sources of variability in exposition to treatment are both their city of residence and cohorts. Data regarding exposition to treatment (percentage of schools that implemented the reform or school construction to allow the extension in compulsory education) are obtained from the administrative records of the Argentine National Education Ministry.

\section{Exogeneity}

One of the major methodological concerns about the approaches that exploit the regional variability in the timing or intensity of a policy intervention is that the choice of the local governments as to when and how to implement the reform may be correlated with unobservable factors which also affect outcomes. In our case, for instance, one may conjecture that poorer provinces with lower enrollment rates could have been more eager to put into effect the changes, since they will be granted resources from the central government.

In order to better understand the timing of the implementation of the LFE, we estimate a hazard model (Jenkins, 1995) of the probability of implementing the reform. We are interested in examining whether there are factors which could be affecting labor market/educational outcomes and the probability of implementing the reform. In table 3 we present our estimates of the hazard model. We model the probability that a province implements the reform at a given period of time as a function of time varying provincial variables. There are several specifications for the left-hand variable and for the time variables. ${ }^{5}$ Among the explanatory variables we consider proxies for regional GDP (gdp), Gini coefficient (Gini), unemployment (Desempleo), population (Poblac), fiscal deficit (Resultado fiscal), political party (polity), which takes the value of 1 if the province is governed by the same party than the national government at the time of reform, and the percentage of individual with unmet basic needs (NBI).

The only variable that is significant in most of the specifications is the political party, which means that the provinces were more likely to implement the LFE if its ruling party was the same than the national one. Given this, we control for this variable in our estimations. The rest of the variables, which are correlated with economic shocks and

\footnotetext{
${ }^{5}$ We considered "implementation" to several different thresholds: $33 \%$ percent of implementation and $90 \%$ of implementation of EGB and Polimodal.
} 
could be also correlated with our outcome variables of interest are uncorrelated with the probability of reform. If the reform is uncorrelated with observed time varying factors, it is less likely that it is correlated with unobserved time varying factors which could be affecting also our outcomes of interests.

As mentioned above, our identification assumption is that in the absence of the reform, educational and labor outcome measures would not systematically differ across provinces which implemented and the ones that not. If this is the case, then the difference in outcomes observed between exposed and non exposed cohorts/regions are attributable to the educational reform.

Table 4 performs some checks in order to support our identification strategy. ${ }^{6}$ Based on individuals' ages and region of residence we can split our sample according to exposition to reform. In Panel I we examine the simple difference in years of education between provinces which implemented massively vs. the ones who did not. While young cohorts are the ones exposed to the new law, old cohorts are not since they were born before they could be affected by the educational reform. The double difference between these two groups amounts to 0.91 years of education and it is statistically significant. Panel II and III show differences by the degree of implementation by age cohorts who should not have been affected by the reform. In both panels both groups (young and old) are comprised by people not exposed to the reform. The double difference in both panels is not statistically significant. This supports our claim that our results are driven by the reform under study and not by other factors.

\section{Education and labor market outcomes}

We carry out the estimations using several samples and different cohorts' definitions. The samples we consider are the following: all individuals, males, poor, and poor males. ${ }^{7}$ We conduct our estimations for three different definitions of cohorts in order to give more robustness to our estimates (see table 5). As left-hand-side variables, we consider two education variables - years of education and a dummy for complete high school - and a set of labor variables - labor income, weekly hours worked, and a dummy for employed.

\section{Education outcomes}

Tables 6 and 7 show the results for the education variables from two models; the effect of the reform is captured by the interaction of a dummy identifying the "young cohorts" (i.e. those individuals young enough to be exposed to the reform) with a variable measuring the intensity of the reform. In the first one the intensity of the reform is introduced through a single binary variable $(=1$ for those individuals living a city that massively implemented the LFE), while in the second one the intensity of the reform is measured by the share of schools that had adopted the reform by 1998 in the area where the individual lives. Results vary more across samples than across definitions of cohort. Results do not qualitatively change if we consider other measures for reform intensity (e.g. school construction). Besides the typical set of controls, we also include political party in the regressions, given its significance in the hazard models of table 3.

\footnotetext{
${ }^{6}$ This analysis follows closely the one in Duflo (2001).

${ }^{7}$ We consider a person to be poor if (s)he belongs to the bottom three quintiles of the household equivalent income distribution.
} 
The LFE seems to have had a significant effect on some basic school enrollment outcomes. The coefficients of the treatment variable indicator (interaction of age in 1996 and treatment variable) are positive and significant for all samples and cohort definitions. Youths fully exposed to the LFE ended up with more years of education than those not fully exposed to the reform. Coefficients range from 0.3 to 0.8 extra years of education as a result of the reform. Moreover, most coefficients are also positive and significant in the case of the binary variable for complete high school. In particular they are positive for poor people, implying at least a partial success of the reform: poor youngsters exposed to the reform ended up with better educational outcomes than those not fully exposed to the reform. The impact, however, seems small: education for those poor youths fully exposed to the LFE increased in about just half a year. The increase is somewhat larger for the sample of all people. One possibility beyond this result is that the reform caused some poor teenagers to finish high school, but few of them to go beyond that. Instead, the impact could have been more intense on non-poor youths, who probably live in an environment more prone to education, and have higher opportunities to continue studying.

The impact of the reform on educational outcomes seems to have been higher for males than for females. This is consistent with the fact that in Argentina, as in most of Latin American countries, high-school drop-out rates are higher for men than for women. CEDLAS (2009) reports that in 2006 while $84 \%$ of females in secondary school age are attending that educational level, the share for males is $78 \%$.

Figure 4 shows coefficients for the interaction of age in year 1996 and treatment when taking years of education as the outcome variable. As expected, coefficients are positive and significant for children aged 8 to 12 years (i.e. those fully exposed to the LFE), and become non-significant after the age of 12 (i.e. for those youths that were finishing or had finished primary school at the time the reform was implemented).

\section{Labor outcomes}

The impact of the education reform on labor outcomes can be studied with the help of tables 8 and 9 . When introducing the reform as a binary variable the results in terms of labor market outcomes are mostly positive and statistically significant. Youths fully exposed to the reform when they were teenagers have now higher probability of being employed, work more hours and earn higher incomes. The reform increased the probability of employment for all individuals and for the group of males. The probability of employment in those groups increases between 4.9 and $7.4 \%$. The effect for poor individuals and poor males is also positive, but in most cases not statistically significant at the conventional levels.

Labor incomes for treated youths are around 10\% higher than for their non-treated counterparts. Results are similar for the sample of males, but almost completely vanish in the sample of poor youths. The reform seems to have had no effect on the labor outcomes of income-deprived people. Most results are also non-significant when considering the intensity of treatment (table 9). Positive and significant coefficients remain only for the sample of all youths and definition of cohort C. Again, all results for the poor are non-significant. The same pattern observed for employment is observed for hours worked. While the entire sample and all males increased their hours worked per week between 2.28 and 3.53, the effect for poor individuals is negligible and not statistically significant. For an average working week of 35 hours, the increase in hours amounts from 8 to $10 \%$. 
In summary, the reform seems to have had an overall positive impact on education and labor outcomes. On average, youths fully exposed to the LFE have more years of education, were more likely to have completed secondary school, have higher probability of finding a job, work more hours and earn higher salaries. However, the effects are in general rather small and some of them do not hold in all specifications. In addition, and more important, the impact of the reform on the income-deprived youths is small for education outcomes and null for labor outcomes. Relatively few poor teenagers exposed to the reform managed to increase high-school education, with apparently no impact on their labor outcomes.

One possible explanation for the differences across groups runs as follows. Poor people have very limited access to jobs with high returns to education. Most of them are construction workers, domestic servants, or are self-employed in the commerce sector. The environment where they grow (low social capital, scarce contacts) implies a substantial constraint to the access to jobs where education makes a big difference. As the reform implied only small gains in years of education, the impact on the performance in the labor market for these people was understandably low. In contrast, the educational gains were larger for the non-poor given the types of jobs that these people are more likely to hold (e.g. civil servants).

\section{Conclusions}

High dropout rates in developing countries have long motivated changes in educational systems in order to keep individuals in school. In most developing countries, education still remains an important policy for leveling off different labor market opportunities. While evidence on the (sometimes causal) relationship of time spent at school and improvements in labor market is well established for developed countries, evidence for developing countries is much scarcer. It is believed, however, that increasing the average years of education for individuals will enhance their labor market opportunities. While it is very difficult to legally enforce the number of compulsory years, it is believed that reforms raising the number of compulsory years and/or school leaving age are effective. Different channels may be behind this. Among them we can mention (Oreopoulos 2009) social norms and the stigma caused by not fulfilling what should be mandatory. For the case of Argentina, we believe that the most pressing concern is the difficulty of finding a job in the formal sector without the legal educational requirements.

Argentina, while still one of the countries with the greater number of years of education in Latin America, still presents a high dropout rate after elementary school, especially for poorer individuals. Henceforth, the reform under analysis here, among other changes, aimed at increasing the average number of compulsory years at school.

In spite of the heated debate about the educational reform in Argentina, there has not been solid evidence of its causal effect on educational and labor market outcomes. This paper contributes to the measurement of the impact of the LFE in different dimensions. Our analysis takes advantage of the variation both of the timing -early vs. late- and the intensity -full vs. gradual- of the reform across Argentine provinces.

Our results suggests positive effects of the reform in some educational outcomes (years of education and high school completion) and labor outcomes (employment, hours and labor income). However the LFE seems to have been only partially successful, as the impact on the income-deprived youths was small for education outcomes and null for labor outcomes. 


\section{References}

Acemoglu, Daron and Joshua Angrist, (2000). "How Large are the Social Returns to Education? Evidence from Compulsory Schooling Laws," NBER Macroeconomics Annual, Vol. 15 pp. 9-59

Angrist, J. and Krueger, A.(1991), "Does Compulsory School Attendance Affect Schooling and Earnings?," Quarterly Journal of Economics

Berlinski, S., Galiani, S. and Gertler, P. (2006). "The Effect of Pre-Primary Education on Primary School Performance". William Davidson Institute Working Paper No. 838 Available at SSRN: http://ssrn.com/abstract=929172

Black, Sandra, Paul J. Devereux \& Kjell G. Salvanes, (2005). "Why the Apple Doesn't Fall Far: Understanding Intergenerational Transmission of Human Capital," American Economic Review, American Economic Association, vol. 95(1), pages 437-449, March

Braslavsky, C. (1999):. La reforma educativa en la Argentina: Avances y desafíos. Propuesta Educativa 21, 80-88.

CEDLAS (2009): Socio-Economic Database for Latin America and the Caribbean. Available at http://www.depeco.econo.unlp.edu.ar/cedlas/sedlac

Cervini, Rubén (2003). "Diferencias de resultados cognitivos y no-cognitivos entre estudiantes de escuelas públicas y privadas en la educación secundaria de Argentina: Un análisis multinivel." Education Policy Analysis Archives 11, no. 6. (February 2003). Available online at: http://epaa.asu.edu/epaa/v11n6/

Coleman, J., Campbell, E., Hobson, C., McPartland, J., Mood, A., Weinfield, F. \& York, R. (1966). Equality of educational opportunity. Washington, DC, US Government Printing Office.

Crosta, Facundo (2007). "Exploring the effects of the school levels reform on access and its quality: The Education Federal Law of Argentina". Well-Being and Social Policy Magazine Vol 3, Num 1, pp. 97-122. Inter-American Conference on Social Security.

Chou, Liu, Grossman and Joyce (2007): Parental Education and Child Health: Evidence From a Natural Experiment in Taiwan. National Bureau of Economic Research, Working Paper 13466

Duflo, E. (2001): Schooling and labor market consequences of school construction in Indonesia: evidence from an unusual policy experiment, American Economic Review 91

Eskeland, Gunnar, and Deon Filmer (2002). "Autonomy, Participation and Learning in Argentine Schools: Findings and their implications for Decentralization" World Bank Policy Research Paper Series No. 2766.

Galiani, S., Gertler, P and Schargrodsky, E. (2007):. Helping the Good Get Better, but Leaving the Rest Behind, Journal of Public Economics

Galiani, Sebastián and Ernesto Schargrodsky (2002). "Evaluating the Impact of School Decentralization on Educational Quality", Economía, 2 (2), pp. 275-302. 
Gorostiaga, J., Acedo, C. and Xifra, S. Secondary Education in Argentina during the 1990s: The Limits of a Comprehensive Reform Effort Education Policy Analysis Archives, volume 11, Number 17

Habibi, Nadir, Cindy Huang, Diego Miranda, Victoria Murillo, Gustav Ranis, Mainak Sarkar, y Frances Stewart (2001) "Decentralization in Argentina", Yale Economic Growth Center Discussion Paper No. 825.

Harmon; Colm and lan Walker, (1995). "Estimates of Economic Return to Schooling in the UK," Economics, Finance and Accounting Department Working Paper Series n540195, Department of Economics, Finance and Accounting, National University of Ireland - Maynooth.

Jencks, C., Smith, M., Ackland, H., Bane, M., Cohen, D. Gintis, H., Heyns, B. and Michelson, S. (1972). Inequality: A reassessment of the effects of family and schooling in America. New York: Basic Books.

Lochner, Lance and Enrico Moretti, (2004). "The Effect of Education on Crime: Evidence from Prison Inmates, Arrests, and Self-Reports," American Economic Review, American Economic Association, vol. 94(1), pages 155-189, March

Llach, Juan, and Francisco Schumacher (2004). "Escuelas ricas para los pobres La discriminación social en la educación primaria argentina, sus efectos en los aprendizajes y propuestas para superarla." Publicaciones AAEP. Buenos Aires: Asocación Argentina de Economía Política, 2004. Available online at: http://www.aaep.org.ar/espa/anales/resumen04/Llach-Schumacher.html

Llach, J., Roldán, F. and Montoya, S. (1999): Educación para Todos. IERAL, Córdoba.

Rivas, A (2003): Mirada Comparada de los Efectos de la Reforma Educativa en las Provincias. Serie de Estudios sobre el Estado, el Poder y la Educación en la Argentina, Documento № 2

Oreopoulos, Philip , (2006). "The compelling effects of compulsory schooling: evidence from Canada," Canadian Journal of Economics, Canadian Economics Association, vol. 39(1), pages 22-52, February

Tiongson, Erwin (2005). "Education policy reform." Chapter in Analyzing the distributional impact of reforms, edited by: Aline Coudouel, and Stefano Paternostro. Washington, D.C.: The World Bank.

Webbink, Dinand (2005). "Causal Effects in Education." Journal of Economic Surveys 19, no. 4 (September 2005): 535-60. 
Table 1

Educational structure before and after the reform

\begin{tabular}{|c|c|c|c|c|c|c|}
\hline \multirow[b]{2}{*}{ Age } & \multicolumn{3}{|c|}{ Before the LFE } & \multicolumn{3}{|l|}{ After the LFE } \\
\hline & Levels & Year & Compulsory? & Levels & Year & Compulsory? \\
\hline 3 & Pre-primary & 1 & No & Pre-primary & 1 & No \\
\hline 4 & Pre-primary & 2 & No & Pre-primary & 2 & No \\
\hline 5 & Pre-primary & 3 & No & Pre-primary & 3 & Yes \\
\hline 6 & Primary & 1 & Yes & EGB & 1 & Yes \\
\hline 7 & Primary & 2 & Yes & EGB & 2 & Yes \\
\hline 8 & Primary & 3 & Yes & EGB & 3 & Yes \\
\hline 9 & Primary & 4 & Yes & EGB & 4 & Yes \\
\hline 10 & Primary & 5 & Yes & EGB & 5 & Yes \\
\hline 11 & Primary & 6 & Yes & EGB & 6 & Yes \\
\hline 12 & Primary & 7 & Yes & EGB & 7 & Yes \\
\hline 13 & Secondary & 1 & No & EGB & 8 & Yes \\
\hline 14 & Secondary & 2 & No & EGB & 9 & Yes \\
\hline 15 & Secondary & 3 & No & Polimodal & 1 & No \\
\hline 16 & Secondary & 4 & No & Polimodal & 2 & No \\
\hline 17 & Secondary & 5 & No & Polimodal & 3 & No \\
\hline
\end{tabular}

Table 2

The process of LFE implementation

\begin{tabular}{lcc}
\hline \hline Province & Year & Degree \\
\hline Buenos Aires & 1996 & $\mathrm{~F}$ \\
Catamarca & 1999 & $\mathrm{G}$ \\
City of Buenos Aires & $\mathrm{N} . \mathrm{I}$ & \\
Chaco & 1997 & $\mathrm{G}$ \\
Chubut & 1999 & $\mathrm{G}$ \\
Córdoba & 1996 & $\mathrm{~F}$ \\
Corrientes & 1997 & $\mathrm{~F}$ \\
Entre Ríos & 1997 & $\mathrm{~F}$ \\
Formosa & 1998 & $\mathrm{~F}$ \\
Jujuy & 1998 & $\mathrm{G}$ \\
La Pampa & 1997 & $\mathrm{~F}$ \\
La Rioja & 1999 & $\mathrm{G}$ \\
Mendoza & 2000 & $\mathrm{G}$ \\
Misiones & 1998 & $\mathrm{~F}$ \\
Neuquén & 1998 & $\mathrm{G}$ \\
Río Negro & $\mathrm{N} . \mathrm{I}$ & \\
Salta & 1998 & $\mathrm{G}$ \\
San Juan & 1997 & $\mathrm{~F}$ \\
San Luis & 1998 & $\mathrm{~F}$ \\
Santa Cruz & 1998 & $\mathrm{~F}$ \\
Santa Fé & 1997 & $\mathrm{~F}$ \\
Santiago del Estero & 1998 & $\mathrm{~F}$ \\
Tierra del Fuego & 1998 & $\mathrm{G}$ \\
Tucumán & 1998 & $\mathrm{~F}$ \\
\hline Source: Crosta (2007) & &
\end{tabular}

Source: Crosta (2007)

N.I: not implemented

F: full implementation since the beginning

$\mathrm{G}$ : gradual implementation 
Table 3

Hazard model

Time of implementation

\begin{tabular}{|c|c|c|c|c|c|c|c|c|}
\hline \multirow{2}{*}{$\begin{array}{l}\text { Dependent variable } \\
\text { Variables }\end{array}$} & \multicolumn{2}{|c|}{ 33\% polimodal implemented } & \multicolumn{2}{|c|}{ 90\% polimodal implemented } & \multicolumn{2}{|c|}{ 33\% EGB implemented } & \multicolumn{2}{|c|}{ 90\% EGB implemented } \\
\hline & Model 1 & Model 2 & Model 1 & Model 2 & Model 1 & Model 2 & Model 1 & Model 2 \\
\hline \multirow[t]{2}{*}{ pbg } & -0.001 & -0.001 & -0.002 & 0.000 & 0.000 & -0.000 & -0.000 & -0.000 \\
\hline & {$[0.001]$} & {$[0.001]$} & {$[0.001]$} & {$[0.001]$} & {$[0.000]$} & {$[0.001]$} & {$[0.001]$} & {$[0.001]$} \\
\hline \multirow[t]{2}{*}{ gini } & 0.607 & $-15,299$ & 4,650 & $-8,219$ & $-28.235^{*}$ & $-52.549 * *$ & $-10,541$ & $-27,035$ \\
\hline & [11.691] & [14.903] & [14.009] & [18.726] & [14.433] & [23.218] & [15.655] & [21.443] \\
\hline \multirow[t]{2}{*}{ desempleo } & 0.074 & -0.031 & 0.137 & $0.243 *$ & 0.120 & -0.170 & -0.067 & $-0.216^{*}$ \\
\hline & {$[0.071]$} & {$[0.080]$} & {$[0.100]$} & {$[0.135]$} & {$[0.097]$} & {$[0.159]$} & {$[0.085]$} & {$[0.120]$} \\
\hline \multirow[t]{2}{*}{ polity } & -0.088 & 0.341 & $1.705 * *$ & $2.349 * *$ & $2.096 * *$ & 0.509 & $2.134 * *$ & $3.019 * * *$ \\
\hline & [0.603] & [0.664] & {$[0.758]$} & [0.947] & [0.843] & [1.185] & [0.840] & {$[1.153]$} \\
\hline \multirow[t]{2}{*}{ poblac } & 0.005 & 0.019 & 0.005 & -0.044 & 0.026 & 0.055 & 0.005 & 0.024 \\
\hline & {$[0.018]$} & {$[0.016]$} & {$[0.029]$} & {$[0.037]$} & {$[0.036]$} & [0.035] & [0.017] & [0.026] \\
\hline \multirow[t]{2}{*}{ Resultado Fiscal } & -0.001 & -0.001 & -0.001 & $-0.005^{* *}$ & 0.000 & 0.002 & -0.002 & -0.000 \\
\hline & {$[0.002]$} & {$[0.002]$} & {$[0.002]$} & [0.002] & {$[0.002]$} & {$[0.004]$} & {$[0.002]$} & {$[0.003]$} \\
\hline \multirow[t]{2}{*}{$\operatorname{lnt}$} & 1,224 & & 2,690 & & $1.401 * *$ & & $1.662 *$ & \\
\hline & {$[0.772]$} & & {$[1.763]$} & & {$[0.621]$} & & {$[0.858]$} & \\
\hline \multirow[t]{2}{*}{ nbi } & 0.024 & 0.044 & -0.083 & -0.080 & $0.110^{* *}$ & $0.125^{* *}$ & $0.099 *$ & 0.128 \\
\hline & [0.049] & {$[0.056]$} & {$[0.054]$} & {$[0.058]$} & {$[0.044]$} & {$[0.061]$} & {$[0.060]$} & {$[0.083]$} \\
\hline \multirow[t]{2}{*}{ d2 } & & $19.936^{\text {**** }}$ & & $18.015^{* * *}$ & & 17,484 & & $18.067 * *$ \\
\hline & & [2.135] & & {$[8.230]$} & & {$[0.000]$} & & [7.813] \\
\hline \multirow[t]{2}{*}{ d4 } & & 18,552 & & 14,998 & & $21.074^{* * * *}$ & & $17.409^{* *}$ \\
\hline & & {$[0.000]$} & & {$[9.380]$} & & {$[1.571]$} & & [7.976] \\
\hline \multirow[t]{2}{*}{ d5 } & & $22.078 * * *$ & & 19.406 ** & & $22.789^{\text {**** }}$ & & $19.997 * *$ \\
\hline & & [1.892] & & [8.762] & & [1.811] & & [7.926] \\
\hline \multirow[t]{2}{*}{ d6 } & & $23.186^{* * * *}$ & & $21.310^{* * *}$ & & 22.350 **** & & 23.514 *** \\
\hline & & [1.930] & & [8.818] & & {$[2.252]$} & & [8.527] \\
\hline \multirow[t]{2}{*}{ d7 } & & $22.620 * * *$ & & $21.432 * *$ & & $24.089 * * *$ & & $23.913^{* * * *}$ \\
\hline & & [2.256] & & [8.552] & & [2.596] & & [8.560] \\
\hline \multirow[t]{2}{*}{ d9 } & & $22.508 * * *$ & & & & & & $23.488^{* * *}$ \\
\hline & & {$[2.468]$} & & & & & & [9.174] \\
\hline \multirow[t]{2}{*}{ Constant } & $-5,340$ & $-16.769 * * *$ & -8716 & -18830 & 3328 & 0.027 & $-3,284$ & $-13,930$ \\
\hline & [4.925] & [6.182] & [7.193] & {$[0.000]$} & [5.839] & {$[10.396]$} & [5.947] & {$[0.000]$} \\
\hline Observations & 141 & 141 & 181 & 181 & 96 & 96 & 131 & 131 \\
\hline
\end{tabular}

Standard errors in bracket

* significant at $10 \%$; ** significant at $5 \%$; *** significant at $1 \%$

Model (1) has a time trend

Model (2) has temporal dummies.

Source: own calculations based on microdata from EPH (INDEC). 
Table 4

Experiment of interest

Years of education

Panel I

Intensive Non-Intensive Difference

$\begin{array}{lccc}\text { Young } & 10.183 & 10.5 & -0.317 \\ & {[00]} & {[00]} & {[0.044]} \\ \text { Old } & 10.991 & 12.218 & -1.227 \\ & {[00]} & {[0.001]} & {[0.063]} \\ \text { Difference } & -0.809 & -1.718 & \mathbf{0 . 9 1} \\ & {[0.043]} & {[0.054]} & {[\mathbf{0 . 0 7 7}]}\end{array}$

Note: standards erros between brackets

\section{Control experiment 1}

Years of education

Panel II

Intensive Non-Intensive Difference

\begin{tabular}{lccc} 
Young & 9.425 & 10.452 & -1.026 \\
\multirow{2}{*}{ Old } & {$[00]$} & {$[0.001]$} & {$[0.074]$} \\
& 9.118 & 10.217 & -1.098 \\
Difference & {$[00]$} & {$[0.001]$} & {$[0.082]$} \\
& 0.307 & 0.235 & $\mathbf{0 . 0 7 2}$ \\
& {$[0.055]$} & {$[0.079]$} & {$[\mathbf{0 . 1 1}]$}
\end{tabular}

Note: standards erros between brackets

Young= 1920212223

Old=2425262728

Control experiment 2

Years of education

Panel III

Intensive Non-Intensive Difference

$\begin{array}{lccc}\text { Young } & 9.849 & 11.076 & -1.227 \\ & {[0.001]} & {[0.001]} & {[0.086]} \\ \text { Old } & 9.49 & 10.515 & -1.026 \\ & {[0.001]} & {[0.001]} & {[0.096]} \\ \text { Difference } & 0.36 & 0.561 & \mathbf{- 0 . 2 0 2} \\ & {[0.066]} & {[0.089]} & \mathbf{[ 0 . 1 2 9}]\end{array}$

Note: standards erros between brackets

Young $=16,17,18$

Old $=20,21,22$ 
Table 5

Cohorts

\begin{tabular}{lrr}
\hline \hline & Name & \multicolumn{1}{c}{ Ages } \\
\hline \hline Cohort & $\mathrm{A}$ & \\
$\quad$ Young & & $8,9,10,11,12$ \\
Old & & $14,15,16,17,18$ \\
& & \\
$\begin{array}{l}\text { Cohort } \\
\quad \text { Young }\end{array}$ & $\mathrm{B}$ & $8,9,10,11$ \\
$\quad$ Old & & $15,16,17,18$ \\
& & \\
Cohort & $\mathrm{C}$ & $11,12,13$ \\
$\quad$ Young & & $14,15,16$ \\
$\quad$ Old & & \\
\hline Note: age in 1996.
\end{tabular}


Table 6

Impact of educational reform on educational outcomes

Binary variable for reform

\begin{tabular}{|c|c|c|c|c|c|c|}
\hline & Cohort A & Cohort B & Cohort C & Cohort A & Cohort B & Cohort C \\
\hline & \multicolumn{3}{|c|}{ Years of educaion } & \multicolumn{3}{|c|}{ Complete Highschool } \\
\hline \multirow[t]{2}{*}{ All } & $0.733 * * *$ & $0.787 * * *$ & $0.471 * * *$ & 0.023 & $0.026^{*}$ & $0.034 * * *$ \\
\hline & {$[0.179]$} & [0.204] & [0.097] & [0.015] & [0.015] & [0.013] \\
\hline Observations & 59449 & 47339 & 35850 & 59996 & 47797 & 36084 \\
\hline \multirow[t]{2}{*}{ Males } & $0.785 * * *$ & $0.845 * * *$ & $0.606 * * *$ & 0.028 & $0.034 *$ & $0.036 * *$ \\
\hline & [0.184] & [0.217] & {$[0.108]$} & [0.019] & {$[0.020]$} & [0.018] \\
\hline Observations & 29128 & 23213 & 17693 & 29429 & 23466 & 17821 \\
\hline \multirow[t]{2}{*}{ All Poor } & $0.472 * * *$ & $0.527 * * *$ & $0.291 * * *$ & $0.068 * * *$ & $0.076 * * *$ & $0.074 * * *$ \\
\hline & [0.134] & {$[0.160]$} & [0.070] & [0.019] & [0.022] & [0.015] \\
\hline Observations & 32485 & 26002 & 19065 & 32850 & 26302 & 19229 \\
\hline \multirow[t]{2}{*}{ Poor males } & $0.546 * * *$ & $0.605 * * *$ & $0.368 * * *$ & $0.072 * * *$ & $0.083 * * *$ & $0.082 * * *$ \\
\hline & [0.132] & [0.163] & [0.102] & [0.020] & [0.026] & [0.018] \\
\hline Observations & 15521 & 12446 & 9085 & 15722 & 12612 & 9176 \\
\hline
\end{tabular}

Clustered standard errors in brackets

* significant at 5\%; ** significant at $1 \%$

All regressions include city and cohort fixed effects

Source: own calculations based on microdata from EPH (INDEC).

Table 7

Impact of educational reform on educational outcomes

Intensity of reform=share reformed schools

\begin{tabular}{|c|c|c|c|c|c|c|}
\hline & Cohort A & Cohort B & Cohort $\mathrm{C}$ & Cohort A & Cohort B & Cohort $\mathrm{C}$ \\
\hline & \multicolumn{3}{|c|}{ Years of educaion } & \multicolumn{3}{|c|}{ Complete Highschool } \\
\hline \multirow[t]{2}{*}{ All } & $0.007 * * *$ & $0.008 * * *$ & $0.005^{* * *}$ & 0.00 & 0.00 & $0.000 * *$ \\
\hline & {$[0.002]$} & {$[0.002]$} & {$[0.001]$} & {$[0.000]$} & {$[0.000]$} & {$[0.000]$} \\
\hline Observations & 59449 & 47339 & 35850 & 59996 & 47797 & 36084 \\
\hline \multirow[t]{2}{*}{ Males } & $0.008 * * *$ & $0.009 * * *$ & $0.006 * * *$ & 0 & 0 & 0 \\
\hline & [0.002] & [0.002] & {$[0.001]$} & {$[0.000]$} & {$[0.000]$} & {$[0.000]$} \\
\hline Observations & 29128 & 23213 & 17693 & 29429 & 23466 & 17821 \\
\hline \multirow[t]{2}{*}{ All Poor } & $0.005 * * *$ & $0.006 * * *$ & $0.003 * * *$ & $0.001 * *$ & $0.001 * * *$ & $0.001 * * *$ \\
\hline & [0.002] & [0.002] & {$[0.001]$} & {$[0.000]$} & {$[0.000]$} & {$[0.000]$} \\
\hline Observations & 32485 & 26002 & 19065 & 32850 & 26302 & 19229 \\
\hline \multirow[t]{2}{*}{ Poor males } & $0.006 * * *$ & $0.007 * * *$ & $0.004 * * *$ & $0.000 *$ & $0.001 *$ & $0.001 * * *$ \\
\hline & {$[0.001]$} & [0.002] & {$[0.001]$} & {$[0.000]$} & [0.000] & {$[0.000]$} \\
\hline Observations & 15521 & 12446 & 9085 & 15722 & 12612 & 9176 \\
\hline
\end{tabular}

Clustered standard errors in brackets

* significant at 5\%; ** significant at $1 \%$

All regressions include city and cohort fixed effects

Source: own calculations based on microdata from EPH (INDEC). 
Table 8

Impact of educational reform on labor outcomes

Binary variable for reform

\begin{tabular}{|c|c|c|c|c|c|c|c|c|c|}
\hline & Cohort A & Cohort B & Cohort C & Cohort A & Cohort B & Cohort C & Cohort A & Cohort B & Cohort C \\
\hline & & Employed & & & ours worke & & & labor incom & \\
\hline \multirow[t]{2}{*}{ All } & $0.063^{* *}$ & $0.074^{* *} *$ & $0.049 * *$ & $3.093^{* * *}$ & $3.261^{* * *}$ & $2.280^{* * * *}$ & $0.139 * * *$ & $0.152 * * *$ & $0.135^{* * * *}$ \\
\hline & {$[0.029]$} & {$[0.034]$} & {$[0.020]$} & [1.132] & [1.328] & {$[0.770]$} & [0.041] & [0.037] & [0.044] \\
\hline Observations & 59998 & 47799 & 36083 & 59998 & 47799 & 36083 & 15703 & 12390 & 10427 \\
\hline \multirow[t]{2}{*}{ Males } & $0.058^{*}$ & $0.065^{*}$ & $0.058^{* *}$ & $3.170^{* *}$ & $3.239^{* *}$ & $3.552 * * *$ & $0.194 * * *$ & $0.223 * * *$ & $0.203^{* * *}$ \\
\hline & [0.030] & [0.037] & {$[0.023]$} & {$[1.272]$} & [1.504] & [1.204] & {$[0.038]$} & {$[0.038]$} & {$[0.050]$} \\
\hline Observations & 29431 & 23468 & 17820 & 29431 & 23468 & 17820 & 9742 & 7692 & 6474 \\
\hline \multirow[t]{2}{*}{ All Poor } & 0.034 & 0.03 & $0.036^{* *}$ & 1.063 & 1.01 & 0.371 & -0.007 & 0.028 & 0.031 \\
\hline & {$[0.026]$} & [0.029] & {$[0.018]$} & [1.035] & [1.151] & [1.067] & [0.046] & {$[0.052]$} & {$[0.061]$} \\
\hline Observations & 32852 & 26304 & 19229 & 32852 & 26304 & 19229 & 9150 & 7149 & 6098 \\
\hline \multirow[t]{2}{*}{ Poor males } & 0.044 & 0.032 & 0.053 & 1.921 & 1.656 & 1.232 & 0.051 & $0.118 * * *$ & 0.051 \\
\hline & {$[0.033]$} & {$[0.034]$} & {$[0.035]$} & [1.423] & [1.629] & [1.839] & [0.048] & {$[0.043]$} & {$[0.053]$} \\
\hline Observations & 15724 & 12614 & 9176 & 15724 & 12614 & 9176 & 5941 & 4666 & 3928 \\
\hline
\end{tabular}

Clustered standard errors in brackets

* significant at 5\%; ** significant at $1 \%$

All regressions include city and cohort fixed effects

Source: own calculations based on microdata from EPH (INDEC).

Table 9

Impact of educational reform on labor outcomes

Intensity of reform=share reformed schools

\begin{tabular}{|c|c|c|c|c|c|c|c|c|c|}
\hline & Cohort A & Cohort B & Cohort C & Cohort A & Cohort B & Cohort C & Cohort A & Cohort B & Cohort C \\
\hline & \multicolumn{3}{|c|}{ Employed } & \multicolumn{3}{|c|}{ hours worked } & \multicolumn{3}{|c|}{ labor income } \\
\hline \multirow[t]{2}{*}{ All } & 0.001 & 0.001 & $0.001 * *$ & 0.021 & 0.021 & $0.020^{* * *}$ & 0.001 & $0.001^{*}$ & $0.001^{\text {**** }}$ \\
\hline & {$[0.000]$} & {$[0.000]$} & {$[0.000]$} & [0.014] & [0.017] & {$[0.009]$} & {$[0.000]$} & {$[0.000]$} & {$[0.000]$} \\
\hline Observations & 59998 & 47799 & 36083 & 59998 & 47799 & 36083 & 15703 & 12390 & 10427 \\
\hline \multirow[t]{2}{*}{ Males } & 0.001 & 0.001 & $0.001 * *$ & 0.023 & 0.02 & $0.029^{*}$ & $0.001^{* *}$ & $0.002 * * *$ & $0.002^{* * *}$ \\
\hline & {$[0.000]$} & {$[0.000]$} & {$[0.000]$} & [0.018] & [0.021] & {$[0.015]$} & {$[0.001]$} & {$[0.000]$} & {$[0.001]$} \\
\hline Observations & 29431 & 23468 & 17820 & 29431 & 23468 & 17820 & 9742 & 7692 & 6474 \\
\hline \multirow[t]{2}{*}{ All Poor } & 0 & 0 & 0 & 0.006 & 0.008 & 0.001 & 0 & 0 & $0.001 *$ \\
\hline & {$[0.000]$} & {$[0.000]$} & {$[0.000]$} & [0.014] & {$[0.016]$} & [0.014] & {$[0.000]$} & {$[0.000]$} & [0.001] \\
\hline Observations & 32852 & 26304 & 19229 & 32852 & 26304 & 19229 & 9150 & 7149 & 6098 \\
\hline \multirow[t]{2}{*}{ Poor males } & 0 & 0 & 0 & 0.008 & 0.006 & -0.003 & 0 & $0.001 *$ & 0.001 \\
\hline & {$[0.000]$} & {$[0.000]$} & {$[0.000]$} & [0.019] & {$[0.022]$} & {$[0.023]$} & {$[0.000]$} & {$[0.000]$} & {$[0.000]$} \\
\hline Observations & 15724 & 12614 & 9176 & 15724 & 12614 & 9176 & 5941 & 4666 & 3928 \\
\hline
\end{tabular}

Clustered standard errors in brackets

* significant at 5\%; ** significant at $1 \%$

All regressions include city and cohort fixed effects

Source: own calculations based on microdata from EPH (INDEC). 


\section{Figure 1}

Gross enrollment rates by age group

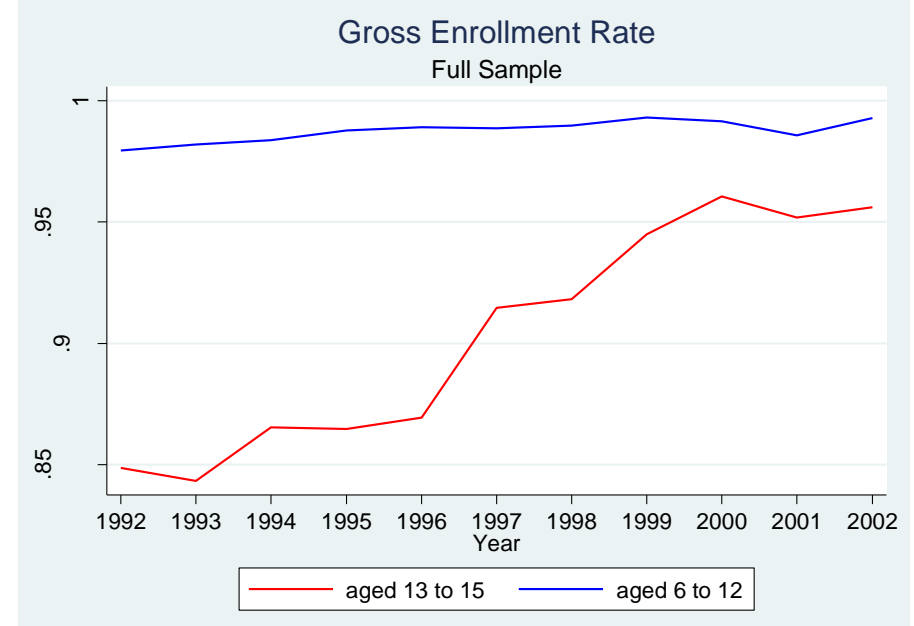

Source: own calculations based on microdata from EPH (INDEC).

\section{Figure 2}

Gross enrollment rates by timing of the reform

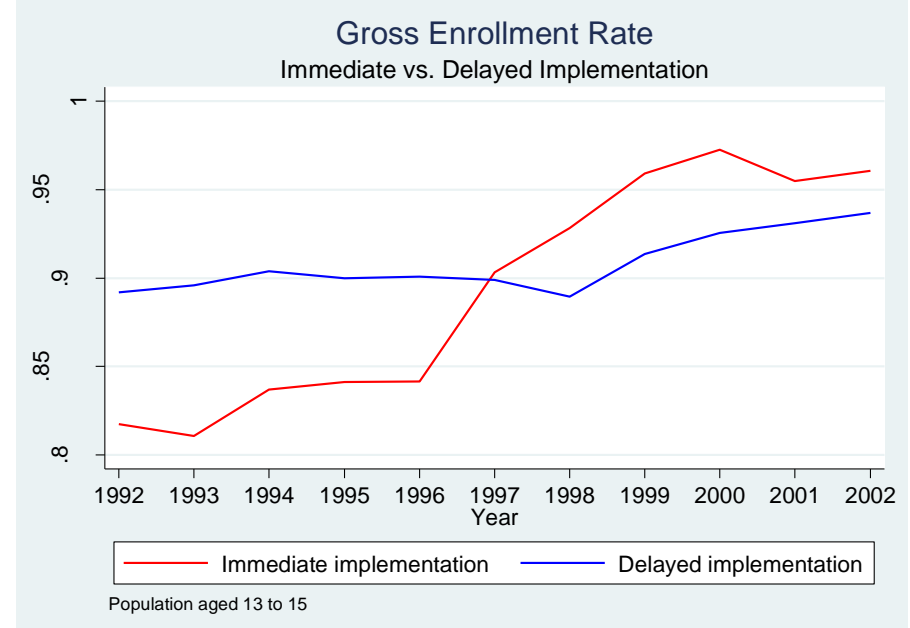

Source: own calculations based on microdata from EPH (INDEC). 


\section{Figure 3}

Gross enrollment rates by degree of the reform

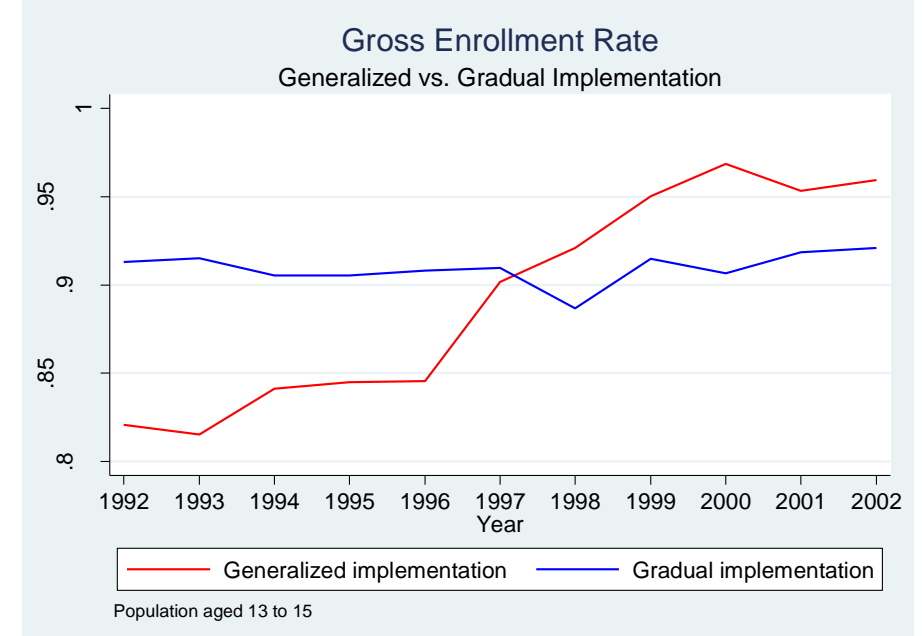

Source: own calculations based on microdata from EPH (INDEC).

\section{Figure 4}

Coefficients of the interaction of age in 1996 with program intensity in the province

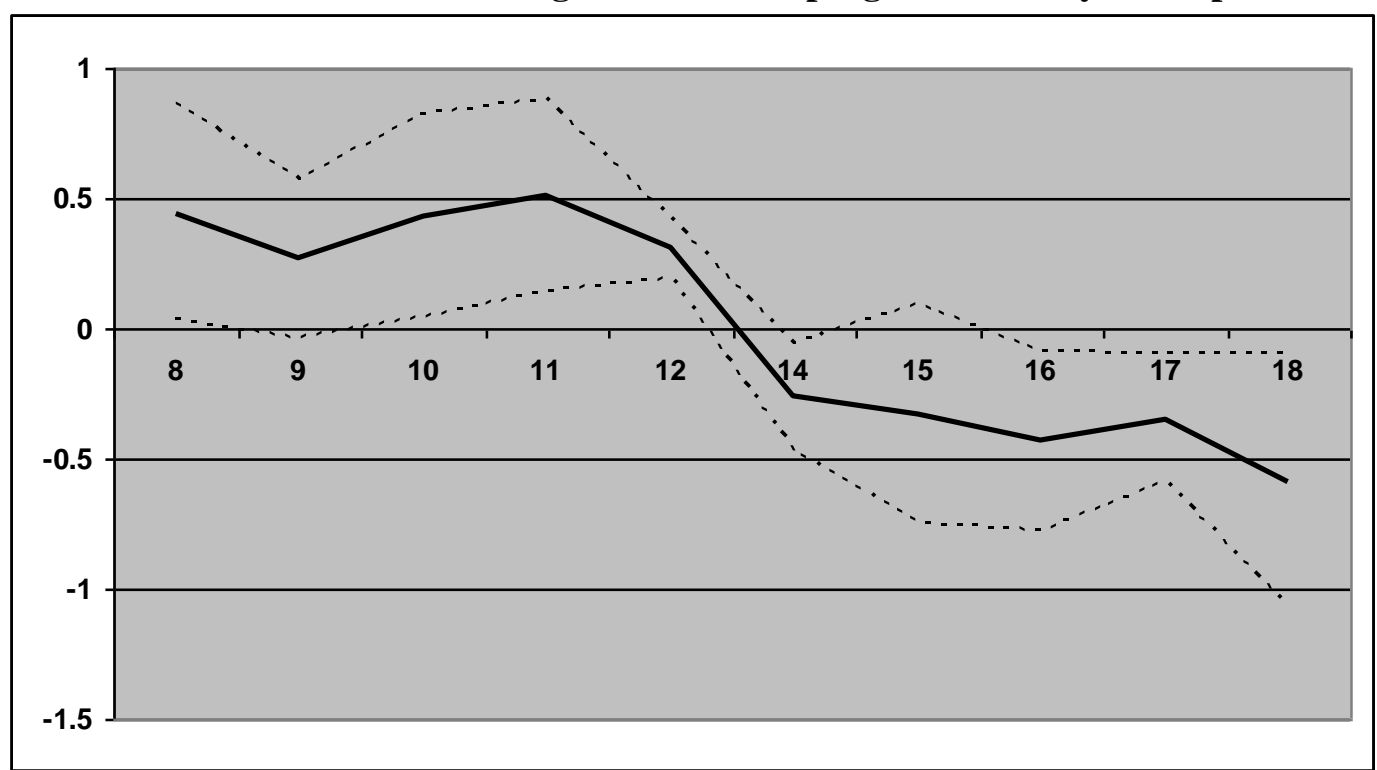

Source: own calculations based on microdata from EPH (INDEC). 